Article

\title{
RESCUING POLITICAL THEORY FROM FACT-INSENSITIVITY
}

\author{
KAI NIELSEN \\ Department of Philosophy, University of Calgary and Concordia University. \\ Calgary and Montreal, Canada. ${ }^{1}$
}

\begin{abstract}
G. A. Cohen, in his Rescuing Justice and Equality, argues that fundamental moral principles do not rest on factual grounds. I contest that and
\end{abstract}

\begin{abstract}
${ }^{1}$ Kai Nielsen (BA, University of North Carolina; PhD Duke University) is Professor Emeritus of Philosophy at the University of Calgary and Adjunct Professor of Philosophy at Concordia University (Montreal). He lives in Montreal, Quebec. Books relevant to Socialist Studies either written or edited by Nielsen include: Equality and Liberty: A Defense of Radical Egalitarianism (Totowa, NJ: Rowman and Allenheld, 1985); Marx and the Moral Point of View: Morality, Ideology and the Moral Point of View (Boulder, CO: Westview Press, 1989); On Transforming Philosophy (Boulder, CO: Westview Press, 1995); Globalization and Justice (Amherst, NY: Humanity Books, 2003); Marx and Morality (co-edited with Steven Patten, Calgary, AB: University of Calgary Press, 1989); Science, Morality and Feminist Theory (co-edited with Marsha Hanen, Calgary, AB: University of Calgary Press, 1989); and Analyzing Marxism (co-edited with R. X. Ware, Calgary, AB: University of Calgary Press, 1989). Also of interest: Michel Seymour and Matthias Fritsche, eds., Reason and Emancipation: Essays on the Philosophy of Kai Nielsen (Amherst, NY: Humanity Books, 2007); David Rondel and Alexander Sager, eds., Pessimism of the Intellect and Optimism of the Will: Kai Nielsen's Selected Political Philosophy (Calgary, AB: University of Calgary Press, 2012).
\end{abstract}

Kai Nielsen (BA, University of North Carolina; PhD Duke University) est professeur émérite de philosophie à l'University of Calgary et professeur associé de philosophie à Concordia University (Montreal). Il a écrit ou dirigé de nombreux livres, dont plusieurs sont d'un intérêt direct pour Etudes Socialistes: Equality and Liberty: A Defense of Radical Egalitarianism (Totowa, NJ: Rowman and Allenheld, 1985); Marx and the Moral Point of View: Morality, Ideology and the Moral Point of View (Boulder, CO: Westview Press, 1989); On Transforming Philosophy (Boulder, CO: Westview Press, 1995); Globalization and Justice (Amherst, NY: Humanity Books, 2003); Marx and Morality (co-dirigé avec Steven Patten, Calgary, AB: University of Calgary Press, 1989); Science, Morality and Feminist Theory (co-dirigé avec Marsha Hanen, Calgary, AB: University of Calgary Press, 1989); et Analyzing Marxism (co-dirigé avec R. X. Ware, Calgary, AB: University of Calgary Press, 1989). Egalement d'intérêt: Michel Seymour et Matthias Fritsche, (dirs)., Reason and Emancipation: Essays on the Philosophy of Kai Nielsen (Amherst, NY: Humanity Books, 2007); David Rondel et Alexander Sager, (dirs), Pessimism of the Intellect and Optimism of the Will: Kai Nielsen's Selected Political Philosophy (Calgary, AB: University of Calgary Press, 2012). 
argue instead that all fundamental moral principles (indeed, all moral principles) are fact-sensitive. They are the most deeply embedded principles in an interdependent web of beliefs-beliefs which include factual beliefs. Indeed, all functioning moral beliefs, moral principles and moral practices are in such interdependent webs. There are no fundamental moral principles which are fact-insensitive. What is fundamental are the most deeply embedded moral principles in interdependent webs of belief and practice. If you will, forms of life.

\section{Resumé}

G.A. Cohen, dans son livre Rescuing Justice and Equality, maintient que les principes moraux fondamentaux ne reposent pas sur des bases factuelles. Je conteste cette idée et argumente que tous les principes moraux fondamentaux (en fait tous les principes moraux) sont sensibles aux faits. $\mathrm{Ce}$ sont les principes les plus profondément enracinés dans des faisceaux de croyances interdépendantes - croyances qui comprennent des croyances factuelles. Toutes les croyances et pratiques, tous les principes moraux fonctionnels sont pris dans ce genre de faisceaux interdépendants. II n'y a pas de principes moraux fondamentaux qui soient insensibles aux faits. Plus ils sont fondamentaux, plus les principes moraux sont profondément enracinés dans des faisceaux interdépendants de croyances et de pratiques. Ainsi en est-il des façons de vivre.

\section{Key Words}

anti-fundamentalist; fact-insensitive principles; fundamentalist; practices; reflective equilibrium

\section{Mots-clés:}

anti-fondamentaliste; équilibre réflexif; fondamentaliste; pratiques; principes insensibles aux faits

It is the burden of Chapter 6 of G. A. Cohen's Rescuing Justice and Equality to establish that "fundamental principles, that is principles that are not derived from other principles, do not rest on factual grounds" (Cohen 2008a, 278). I shall contest that. There are, I shall argue, no fundamental principles-something like a first cause or some necessity on which all contingencies rest-in Cohen's traditional sense, outside of mathematics and logic. What contrariwise are often and should be called 'fundamental principles' are the most deeply embedded principles in a web of belief or a cluster of practices. As such, they are interdependent with other elements of the web of belief, including factual ones, derived from or interlocked with other propositions (sentences), rules and principles in a system of practices. This argument is close to Rawls, since for Rawls fundamental principles should be understood in a Quinean sense as the most deeply embedded, central, and in that way, the most fundamental, in a web of 
interconnected, interdependent beliefs or cluster of practices. We can put it behaviorally by saying they are the last beliefs we would give up. (Even people with a reasonable clarity of mind may be unaware of what they are and only discover them when under political and moral stress, or they may never discover them at all.) There are no unjustified justifiers on which all justified justifiers rest. Where and how justifications come to an end is always a contingent and contextual matter.

This is perhaps too hedgehoggish. Before I go foxish, or try to, I want to make one further hedgehoggish remark that underlies my argumentative strategy. Cohen, his strikingly brilliant and analytical acuity notwithstanding, writes as if Wittgenstein, Waismann, Sellars, Quine, Davidson, Rorty, Putnam, Hacking and Brandon had never written. I am not claiming these philosophers exhaust the field or that any of them have it just right or that they say the same thing. They manifestly do not. For instance, Wittgenstein, but not Quine, would firmly reject naturalized epistemology, scientism and naturalism. Yet they agree about anti-essentialism, anti-foundationalism, and the rejection of Hegelian radical holism. Rorty is deeply historicist while Quine is not. But together they set out a non-foundationalist, anti-essentialist, fallibilistic, holistic, contextually sensitive perspectivist account of thought along with a suspicion of $a$ priorism doing any substantive work. However, Cohen, with his talk of the nature of justice, justice as such, pure justice, the essence of justice, a priori truths, and a priori selfevident principles, does not face the challenge of such philosophers. He goes in for an essentialist, foundationalist conception of justice for all possible worlds and so sets a task that cannot and need not be carried out. It is remarkable and disconcerting to find a Marxist in Platonic robes taking such issues seriously (Cohen 2008a, 291).

In what follows, we will not get something that will decisively end argument with a final, absolutely true set of substantive principles, including fundamental ones known to be absolutely true for all times, climes and for all possible worlds. But this does not at all mean anything goes. It is true that nothing is decisive. We never escape contingency and fallibilism. But as we bat around the arguments, seeking a more comprehensive, firmer coherence with a wider, more varied battery of considered judgments (what Cohen calls intuitions), we gain a better coherence of such considerations and a more comprehensive, well-warranted view. We do not want an empty coherence. Rather, judgments so intertwined require coherence of considered judgments with some independent warrant, with a wide sampling at all levels of abstraction coherently arranged, with empirical facts and empirically grounded theory. With this we have a coherence of a far wider scope than simply a coherence of considered judgments (moral intuitions); we have a better, more comprehensive coherence (Nielsen 2008).

I claim and seek to show that the best we can hope for is a wide, reflective equilibrium of considered judgments and coherent moral arguments of the kind I set forth in equilibrium, along with empirical observations and arguments nested in a 
coherent whole, and that this best is all we can get and is sufficient. No single observations, but the assembly of the arguments and observations is the strength of a judgement, in keeping with my view that justifications of beliefs occur not through appeal to bald statement or by appeal to timeless, universal principles but through faillibilistic empirically-based and context sensitive inquiry. ${ }^{1}$

\section{II}

I will state briefly Cohen's account of the relationship between facts and normative principles (hereafter simply called principles). Cohen claims that "facts ground principles only in virtue of further principles that are not grounded in facts [principles that are, that is, fact-insensitive] and principles that explain why the given facts ground given [fact-sensitive] principles" (Cohen 2008a, 251). He remarks, "I claim that all principles that reflect facts reflect facts only because they also reflect principles that don't reflect facts, and that the latter principles form the ultimate foundation of all principles, fact-reflecting principles included" (Cohen 2008a, 254).

What Cohen calls his strong thesis, which he takes to be demonstrable, is that it is false "that justice is wholly fact-sensitive" (Cohen 2008b, 6). Cohen claims the very "influence of alien factors [for example, factual considerations] on the output of the constructive procedure [a procedure employed by constructivists for identifying justice] means that what it produces is not fundamental justice and is sometimes not justice at all" (Cohen 2008b, 8). Suppose one asks what the proper role of fundamental principles of justice is. Cohen's answer, pace Rawls, is that they have no proprietary role apart from "the obvious role of spelling out what justice is" (Cohen 2008b, 8). But, as such, justice itself, Cohen claims, has no role.

So how does Cohen argue for these counter-intuitive claims? He says:

The view that all principles for governing human life are sensitive to facts about human life sounds reasonable... but I believe it to be demonstrably mistaken...it cannot be true of all principles that they are sensitive to fact and that it is true of some principles only because it is false of other, fact insensitive, principles which explain why given facts ground fact-sensitive principles... a principle can reflect or respond to a fact only because it is also a response to a principle that is not in response to a fact...principles that

\footnotetext{
${ }^{1}$ I was fortunate in my two anonymous reviewers. However, the first seems to suggest that these metaphilosophical issues can reasonably be resolved or dissolved by bald statement or snappy argument. I would reply that Hillary Putnam is right on in saying that what can be put in a nutshell belongs there. The second reviewer rightly appreciates my argument as an effort to establish a wide reflective equilibrium in response to Cohen's mistaken philosophist quest for absolute, universal and a priori truths.
} 
reflect facts must, in order to reflect facts, reflect principles that don't reflect facts.

My thesis depends on what it is for a principle to be a principle and, more particularly, on what it is for a fact to ground a principle. The thesis is not restricted in scope to principles that are in some or other sense correct. The thesis applies to anyone's principles, be they correct or not, so long as she has a clear grasp both of what her principles are and of why she holds them (where "grasping why she holds them" is short for "knowing what she thinks are the grounds of the principles" rather than for "what causes her to hold them"). It also characterizes (under an appropriate reformulation) whatever (if anything) constitutes the correct set of principles (Cohen 2008a, 332-33).

Cohen illustrates what he is arguing for. He remarks that P1 ("we should help people to pursue their projects") is itself a fact-sensitive principle. We might cite the factual claim in support of P1, that people can achieve happiness only if they are able to pursue their projects. But that in turn requires a more ultimate principle P2 that "absent other considerations, people's happiness should be promoted". Cohen remarks of P2 that "it is possible that there will be no fact on which the principle P2 is grounded" (Cohen 2008a, 235), but merely possible is not the same as actual. P2 might in turn be grounded by the factual claim that promoting people's happiness shows our respect for them, so appealing to the principle (P3) that people ought to be respected. People who argue as they do above must hold P3. But P3, if based on fact, "is based on the fact that people possess what are thought to be respect-meriting characteristics" (Cohen 2008a, 235), which is in turn grounded by the allegedly fact-free principle P4 that we ought to respect beings with respect-meriting characteristics. Note that P4 does not claim that anyone has such characteristics but makes the hypothetical claim that if any being, human or otherwise, has these characteristics then we ought to respect them. This, Cohen claims, is a fact-free principle tout court and thus qualifies as an ultimate fact-insensitive principle. This is where the justificatory and explanatory buck stops.

Has Cohen established "the a priori thesis that, if the facts ground principles, then fact-insensitive principles are the foundation of the structure of the belief of anyone who is clear about what he believes and why he believes it" (Cohen 2008a, 257)? Au contraire, principles, factual beliefs and other beliefs are not justified, explained or even intelligible in utter independence of each other, but are made so (as semantic holism holds) by their fitting together; by their coherence. Some considered beliefs in our systems and practices will sustain initial and even sustained reflection. But for them or other beliefs-factual, normative, or procedural-to be justified, explained or intelligible, they must coherently fit together in what Rawls calls wide reflective equilibrium (Rawls 1999b, 286-302; Nielsen 2008; Ripstein 2010). In their interdependence no principle, except perhaps in formal systems, can be fact-insensitive. 
Some principles are more fundamental and have a more pivotal role in the system of practices. In this non-Cohenian sense, Rawls can call them first or fundamental principles. But none of them are like axioms in a formal system and, even so, axioms require rules of formation and transformation. No single, independent principle serves as the foundation of other principles (Nielsen 1994a; Nielsen 1994b; Nielsen 2008). There is an inescapable entanglement of fact and value (Putman 2002).

\section{III}

Cohen resources to respond to this charge are inadequate. He puts a central claim in hypothetical form, namely that "if there is an explanation of why fact F supports principle $\mathrm{P}$, then it invokes a more ultimate principle that is insensitive to $\mathrm{F}$ " (Cohen 2008a, 236). This is a weaker than his stronger claim, which he thinks is also demonstrable, that there is an "ultimate principle [which] is ultimate [tout court] or factinsensitive [altogether]" as distinct from just being insensitive to some particular fact (Cohen 2008a, 236).

Cohen argues that we can ask anyone:

who affirms a principle on the basis of a fact what further and more ultimate principle explains why that fact grounds that principle and, once that more ultimate principle has been stated, we can again ask whether it in turn is based on any fact, and so on reiteratively as many times as may be required until she [the inquirer] comes to rest with a principle that reflects no fact, unless the sequence of interrogation proceeds indefinitely (Cohen 2008a, 237).

I claim that, in principle at least, such interrogation can go on indefinitely. Though we may finally come back to our initial fact-sensitive premise, we can start all over again appealing to linked different premises in our system of belief, including factsensitive premises in some related system of belief linked with our system of belief. And if the circle is big enough, inclusive enough, it is not a vicious circle. Here we take a lesson from Quine.

Cohen challenges us to produce a credible interrogation that might go on indefinitely. He thinks we will fail. Of course, we will very likely fail since we are not imaginative, intelligent, informed and patient enough to do so. But if some substantive principle will at a given time seem to us fact-insensitive, that doesn't establish it forever. At some later time, we may see that our seemingly fact-insensitive ultimate substantive principle is neither fact-insensitive nor ultimate but just deeply embedded in our structures of belief, in our practices, practices that may change. This indefinite carrying 
on has repeatedly happened in the history of philosophy and indeed in the history of thought or in the changing of our practices. There is no escape from such contingency.

Moreover, there is no need. We are not caught in irrationality or arbitrariness if there is no foundational stopping place, no end of all ends, no last word, no Archimedean point. Remember philosophers as different as Friedrich Waismann and Gilbert Ryle on proofs in philosophy and the lack of theorems proved in philosophy (Waismann 1968, 138; Ryle 1972, 219-23).

We may come to a place-for Cohen various places-where we are tempted to believe of something that it is just self-evident (Cohen 2008a, 236), a resting point with something as empty as 'Good is to be done and evil is to be avoided' [the Thomist first principle of the natural law] or 'Freedom always, everything else being equal, ought to be protected' or Cohen's and my principle, 'Justice is equality'. These principles, some tautological and some not, may be good heuristics in some contexts and they have the smell of both self-evidence and emptiness. And they may be fact-insensitive (Nielsen 1991a, 41-84).

But they are too empty-too thin-to explain why for a grounding principle it grounds. We never get a justificatory argument that there is and for which there can be no alternative to. To avoid pragmatic contradiction, we should say that there seems to be no such reasonable alternative. We are not claiming that what I have just been claiming must be so. Reasoning with Rawls, we might say we require something like "an indefinite nesting of principles", but we do not need an infinite nesting of those interdependencies. With this we do not have, as Cohen thinks, a knockout refutation of Rawls. See Ripstein 2010.

In rejecting a sequence of interrogation that goes on indefinitely, Cohen also remarks,

Finally, with an unending sequence of justifications we would come up against the requirement ... that she who affirms $P$ has a clear grasp of what key principles are and why she holds them: for we can surely say that a person who cannot complete the indicated sequence, because she has to go on forever, does not know why she holds the principles she does (Cohen 2008a, 237).

I have trouble here. She surely can complete the indicated sequences given by Cohen on pp. 234-37. But an interrogator can think that they yield no ultimate fact-insensitive standpoints without being guilty of a failure of clarity. Perhaps she is mistaken as might be her challenger, but that does not mean that either lack clarity. Being clear and being right, as Cohen recognizes himself, do not come to the same thing. And 'perfect clarity', like 'perfect justice', may be, and probably is, a Holmesless Watson. Put more modestly, 
we can, with more or less clarity of mind, go on indefinitely, perhaps ending, if we end at all, in a big circle. Cohen's 'clarity of mind' stipulation, as he calls it, is arbitrary (Cohen 2008a, 237, note 8). Cohen says his "thesis applies to anyone's principles, be they correct or not, so long as she has a clear grasp both of what her principles are and of why she holds them" (Cohen 2008a)). That's fine, but a Cohenite that claims that there is a determinate fact-insensitive ultimate grounding and a Quinean or Davidsonian semantic holist with her system-dependent coherentist justificatory stance or a Rawlsian with his wide reflective equilibrium can equally meet the clarity of mind condition (see also Cohen 2008a, footnote 6 on p. 233).

To be clear need not yet to be right; a clear argument may not be sound. Think, for example, of the ontological argument for the existence of God as it was in Norman Malcolm's hands (Malcolm 1963, 141-62). Perhaps an 'utterly clear' argument must also be correct, but we don't know what an utterly clear argument is and there are no criteria of soundness that are system independent and 'clear to reason'. 'Clear to reason' here is (pace Cohen) just arm waving (Cohen 2000, xvii-xxiii). Moreover, clarity comes in degrees and is context-dependent.

\section{IV}

Cohen, however, has further arguments against such a holism. He states brusquely the holistic position I have been defending and then gives his grounds for rejecting it:

Someone might raise against the third premise of my argument [i.e., that an argument cannot proceed indefinitely] the objection that it presupposes a controversially foundationalist view of justification. On a contrastingly "holist" or "coherentist" view of justification...the indefinite sequence of justificatory interrogation that my third premise seeks to exclude can obtain, harmlessly, because, for every statement, there is a set of statements that justify it: on a holistic view, justifications lie not on a line with a beginning and an end, but on a finite beginningless and endless network of (now branching, now converging) lines of justification that runs through a body of belief and along which one may travel for as long as one likes. The coherentist view...defeats the considerations...in favor of the third premise of my argument: a holistic-justificatory conversation can proceed indefinitely, in the absence of an extravagant proliferation of norms, and reliance on a holistically structured justification is consistent with having a grasp of what one's principles are and of why one holds them...you can go 
on justifying forever with finite belief resources, and... without prejudice to self-understanding (Cohen 2008a, 241-42).

Cohen responds briefly and starkly that "the truths that determine the impact that our statements have upon one another, within the full set of our statements, cannot themselves be treated holistically, on pain of infinite regress" (Cohen 2008a, 242). He cites Thomas Nagel's remark in support: "Not everything can be revised, because something must be used to determine whether a revision is warranted-even if the proposition at issue is a very fundamental one" (Nagel, The Last Word, 65).

We should counter that not everything, as Peirce stressed, can be revised at once. But, over time, nothing is (at least in principle) unrevisable, even that claim itself. (Perhaps the addition at the end of the previous sentence engenders the sense that something is fishy here, but it is hard to say why.) There cannot be a demonstration that something must be unrevisable at time $\mathrm{T} 1$ but that what is unrevisable at $\mathrm{T} 1$ cannot be revisable at T2. Instead, we should just look-even if we interpretively look-and see what is transpiring (something we learn from Ian Hacking). For anything complex, often what at one time was taken to be unrevisable, we take later to be revisable after all. Think of the law of the excluded middle.

That notwithstanding, there will be, as Peirce recognized, acritical commonsense beliefs taken to be universal and truistic: remarks like fire burns or snow often falls in Quebec in January. The first is universally believed where there is fire, the last where Quebec is known in our time frame. (We need not know what it was like on the lands now called Quebec a million years ago.) But neither belief is clearly a priori and their revisability status is unclear. They are not problematic as to their truth, though their logical status may be. But who needs to care about that? Why worry about the logical status of 'Rain is wet'? Nobody, not even philosophers, worry their heads off about such propositions. Moreover, the first is not the a priori truth that Cohen seeks.

Things we are interested in asserting or taking as rock bottom or denying or questioning are not, whether we like it or not, unrevisable or fact-insensitive. I speak here of claims such as 'Sexism and racism are here to stay', 'There is no alternative to capitalism', or, 'We cannot trust our media', and the like. Any of these things might cease to be so, never have been so, or require an amended statement. But, if we are reflective and care about our world and ourselves, we want to know the truth about such matters. And we hope and realize we can get at some probabilistically, warranted assertability here, if inquiry is resolutely carried out, though this always will be time-dependent, contingent and ultimately uncertain matter. Holists, as the later Wittgenstein made plain, can just stick with what we can conscientiously ascertain concerning how things seem after a careful and impartial examination-things we can assert confidently without contradiction and without pragmatic contradiction. 
Cohen has what he takes to be a more substantial reply to holists or molecularists, what he calls quasi-holists (Cohen 2008a, 242):

But my substantial reply to the holism objection is that, even if true, holism (and quasi-holism) do not threaten my proceedings. For consider: within an holistic framework, some statements are sensitive to (certain) others only so indirectly as to be virtually independent of the latter. So, for example, even if holism is true, the facts of human psychology remain virtually insensitive to facts about the distance of some far-flung galaxy from some other one. It would require exposition of an enormous network to connect them: no holist would say: "Well, this psychological theory has a certain recommendation, but we'd better see whether it fits with what seem to be the facts of astronomy." It is always a legitimate question, even for a holist, whether there is any substantial influence of one sort of statement on another, for selected statements, and sometimes the answer is no (Cohen 2008a, 242).

However, Cohen is speaking of 'virtual independence', of 'virtual insensitivity to facts'. In his next paragraph, he says rightly:

My opponents believe in arguments from facts to fundamental principles that do not depend on vast stretches of the total web of belief. They believe in a more 'local' sensitivity of principles to facts, and they must, accordingly, press a localized rather than a general holism against me (Cohen 2008a, 243).

He goes on to say, "I have no reason to deny that fact-insensitive principles themselves form a whole, without priority of some privileged set of them" (Cohen 2008a, 243). Nor need he deny the soundness of employing:

...Geoffrey Sayre-McCord's description of the method of reflective equilibrium, "the process of developing an acceptable moral theory is a matter of shifting back and forth among the various moral judgments one is initially inclined to make and the more or less abstract theoretical principles one is examining and attempting to develop, altering the collection of principles to fit better the judgments and adjusting the judgments to bring them, as best one can, in line with plausible principles" [cited from Sayre-McCord] (Cohen 2008a, 243). 
Then Cohen adds, "What I would deny is an expanded description that adds factual beliefs to the mix (Cohen 2008a, 243). But this is the expanded description that Rawls, Daniels and I deploy in setting out what we call wide reflective equilibrium (Rawls 1999b, 286-302; Daniels 1996; Nielsen 1994a; Nielsen 1994b; Nielsen 2008). It is not enough to attain an adequate reflective equilibrium to just gain a coherence of moral judgments from different levels of moral belief; from specific considered moral judgments, to moral rules, to moral principles, to deeply embedded moral principles expressing our deepest convictions and commitments. Rather the mix, to gain moral adequacy and substance, must also include factual and methodological beliefs and principles and being in this type of this mix robs us of principles that are fact-insensitive as well as non-contingent.

Cohen responds:

But I will find that they [fact-insensitive principles] belong to a fuller whole that also embraces facts challenging only if the contemplated opponents are able to provide an illustration of how a change in one's view of a principle can alter one's belief about the sort of fact that they think supports principles (Cohen 2008a, 243).

It seems to me to be the other way around. What needs to be shown is that principles that Cohen takes to be fact-insensitive really are. Rawlsian holism is a localized holism, though not as localized as Sayre-McCord's and it is not fact-insensitive, instead emphasizing interdependence and the entanglement of fact and value-and Cohen has done nothing to show its inadequacy.

Cohen's claim is at best inconclusive, for he would have to show that in some reasonably localized holism (or molecularism) there would not be some fact that an allegedly factually-insensitive non-empty principle relied on. Here fallibilism comes into play and it becomes relevant to ask if it is more plausible to believe that there are always some foundationalist principles that are logically immune from the possibility of refutation or revision in the light of the facts or if, instead, it is more reasonable to believe that there always is a reasonably localized set of beliefs with a mixture of beliefs factual, normative and methodological where no purely normative principles-fact-insensitive principles-can be asserted, with a priori confidence, that are categorically both substantive and factually insensitive rather than just pragmatically being so-or at least seemingly so-for a time, place and occasion.

Cohen would wager on the former and I on the latter. Do we have a way of reasonably deciding which claim is more plausible? I think so. But is this just foot stamping on my part or on Cohen's, with his nay saying? Moreover, I would make the pragmatist claim - that Cohen would strongly resist, given his conception of political philosophy-that if what we say here makes no practical difference, then there is no 
difference. Is this Luddite? And when philosophical issues are at issue, is it mistaken to be Luddite? Do we run up against something here which is not rationally or reasonably decidable?

V

Counter-examples are the stock and trade of most philosophers, particularly moral philosophers. Cohen abounds in insightful, extraordinary and sometimes humorous counter-examples. A skeptic might say that that enables the unrestricted counter-example devotee to play their distinctive, though rather useless, language-games (Nowell-Smith 1954). But to avoid counter-examples altogether is to lose something like an anchor, as we can see from the writings of C. I. Lewis where they are almost totally absent. As we read Lewis, we long to have a translation into the concrete. Be that as it may, in Cohen's Chapter 6, “The Facts", Cohen deploys two striking weird counterexamples which he thinks reinforces his conclusions (Cohen 2008a, 246-47). I resist the unrestrictedness of counter-examples.

In the first key counter-example, Cohen remarks, "it is bewildering to try to say what principles we would affirm for beings who were otherwise like us in our adult state but whose normal life spans are only twenty four hours" (Cohen 2008a, 246). Would such facts, if they obtained, lead us to different normative principles and indeed different fact-insensitive ultimate moral principles? It should be said that we don't know what "it is about decades that makes their normative significance different [if it does] from that of twenty four hours" (Cohen 2008a, 246). This, Cohen believes, throws us into normative turmoil. Cohen's second counter-example has a similar intended import. Cohen writes,

as a matter of fact, zygote/fetuses become progressively more baby-like as they proceed toward birth. But suppose... for example, that they were initially more baby-like and then regressed to less and less baby-like conditions until the day before they are born, they undergo spectacular humanization (Cohen 2008a, 246-47).

Would we not revisit what are for many our common judgments about the propriety of early versus late abortions?

But these unrealistic counter-examples have the opposite effect of what Cohen intends and show that what he takes to be fact-insensitive principles are really not factinsensitive at all. After all, if our ultimate principles were fact-insensitive these posited differences should make no difference. But for Cohen, they would.

We should affirm the irrelevance of desert-island examples when thinking about what to do, what would be just or desirable or how we should live our lives or our lives together. There are, by contrast, non-desert-island counter-examples. For example, take 
one that exercises Cohen. Suppose the vast majority of people in North America became less Harper-like and less Bush-like neo-liberals cum neo-conservatives and became people with the kind of reciprocity that Cohen defends in Why Not Socialism? (Cohen 2009, 3045) based on a commitment to care for others and in turn, to have a well founded expectation that one will be cared for. This is a characteristic behavior that we as individuals in our capitalist orders do not centrally engage in. Instead, we typically act in ways that will maximally, or at least optimally, serve our interests. But we could-and not just logically could-change and behave reciprocally, at least more often, and not instrumentally for egoistic reasons but because of mutually caring (Sen 2009, 174-93). We actually see this approximated in some societies and by some people in all societies.

Factual beliefs concerning how we behave or realistically could come to behave are relevant here and they affect our moral beliefs and principles, perhaps even our most fundamental moral principles. In so changing our behavior, we might not have any coherent idea of what our ultimate principles are, even if we wonder whether our more fundamental principles had changed. Instead, in acting we just rely on moral intuitions, lower level moral rules and principles which, along with the facts, can yield a coherent wide reflective equilibrium (Nielsen 2008). Through considered judgments based upon an appreciation of the importance of coherence, we forge such an equilibrium (Rawls 1999b, 286-302, 388-420; Nielsen 1994a; Nielsen 1994b; Daniels 1996; Nielsen 2008). We might come to have a socialist morality with an egalitarian ethos distinct from the familiar bourgeois one many of us have now. Or, with Ayn Rand, we might make a virtue of selfishness. Either way, we get fact-sensitive principles and not fact-insensitive substantive principles based on our considered ideas about morality, partially grounded in factual assumptions about what the world is like or what we think the world is like or might realistically be like.

VI

Cohen responds by deploying a bit of meta-philosophy incorporating a possible world's conception and grants that if the world became very different than it is, like in his above mentioned counterfactuals, we would not know what to say when asked what our ultimate warrant would be (Cohen 2008a, 247). We would know that some of our principles would need some changing, but we would be up in the air as to which and how. Cohen then goes on to say:

...we don't need to know what that warrant [an ultimate warrant] is for practical purposes, but (in my view) philosophy's role is not to tell us what we need to know (in that sense), but what we want or ought (for nonpractical reasons) to know. Not all will agree. Some might attack my 
philosophical presuppositions as 'philosophist' (Cohen 2008a, 247; italics mine).

I am one of those. However, for me, Rawls and Daniels, some fact-sensitive principles will be more deeply embedded in the system or the cluster of practices than other principles and in that non-Cohenist but Quinean, fallibilist sense could be called ultimate (fact-sensitive) normative principles. But even that may be too much ultimacy for anyone utilizing a Peircean pragmatist method of belief formation an fixation.

Cohen is right that what some of his convictions would become is unclear if his wild counterfactual situations obtained. Yet even if we accept Cohen's claim that we need all possible worlds' justification for some theoretical philosophical purposes, we should still eschew such possible worlds' philosophy as a language-game we should not and maybe cannot play, on the grounds that moral reasoning or normative political reasoning is practical reasoning. To have the understanding that practical reasoning can yield, we must understand what those practical functions are and (perhaps) why moral reasoning has those functions. But that latter consideration comes down to knowing their rationale, itself a practical question that requires no answer to Cohen's allegedly purely theoretical questions. When we know the practical purposes moral and normative political practices have and the rationale of these practices, we will have all we need to know and perhaps all that we can know about them. And there we are firmly in the domain of fact. And we remain in the sphere of practical reasoning. We should follow the Jamesian, Deweyian, Rortian conception (not the Peircean one) that when two or more verbally distinct distinctions make no practical difference, there is no difference: as Rorty crisply puts it, "if a debate has no practical significance, then it has no philosophical significance" (Rorty 2007, 34).

VII

Cohen might think Rorty's claim too Luddite. But why try to think about the moral contexts of all possible worlds? It is problem enough to grasp what a reasonable conception of justice is for our world, i.e., to understand the actual use of 'justice' well, various conceptions of justice, considerations of a hopefully achievable better world and to evaluate them along with a good understanding of the principles in play in moral reasoning and an understanding of the relevant, basic psychological, social and historical facts of human nature and society. We, as Sen argues, do not need to know what 'pure justice' is either in our world or any merely possible world let alone in all possible worlds (Sen 2009). We do not need to know what harm would come to us if we had metallic-like exoskeletons. If we get a good mastery of how things could on the best case scenarios realistically go in our world, we will have all we need to know concerning what a decent, 
just, caring and humane society and world would look like. Do we need to know whether there are ultimate principles or whether, even if there are, they are all fact-sensitive or fact-insensitive? Do we need, even assuming (which is a lot) we can know, what is true or warranted about justice for all possible (consistently thinkable) worlds?

Shouldn't we stick with the pragmatist claim that if a difference in an argumentmost particularly in moral and political argument-has no practical significance, then it has no philosophical significance either, or indeed any other kind of significance, except for those who like to play games? Shouldn't we say that about significance across the board? Should we not treat issues like Cohenish type questions about whether ultimate principles are fact-insensitive or not, with benign neglect? Yet surely the philosophical establishment, including Cohen, will not like such a pragmatist turn.

VIII

It is fundamental for Cohen-a deep philosophical conviction-that ultimate normative principles are not grounded in facts (Cohen 2008a, 250). In discussing the familiar philosophical conception that ought implies can, he gives a new argument for his deeply embedded philosophical conviction. It goes as follows: If something should be done, then, if it is possible, it should be done. We can see from this, Cohen claims, that we judge the normative independently of its factual possibility. Feasibility doesn't establish the grounds of justice (Cohen 2008a, 252-53). What feasibility establishes instead is when we can implement justice and when we should try to do so. But what is justice, he claims, is determined independently. What causes us to have such a concept of justice (how we get socialized into it), to give it the weight we do and how we can ascertain that or even come to know or be justified in believing what we think we know justice is, is different from the question of what justice is. We have two considerations here, one causal, one epistemological, both distinct, Cohen has it, from determining what justice is. That is a metaethical question about the logical status of ultimate principles of justice. His metaethical thesis is neither a genetic (causal) nor an epistemological one. This, as Cohen admits, may lessen his thesis's interest, but makes clear its uniqueness and, by so limiting his claim, increases its cogency. (See Sections 10 and 16 of Chapter 5 of Rescuing Justice and Equality.)

As Cohen states in two closely related contexts: (1) "We are committed to some fact-insensitive principle whenever we adopt a principle in the light of, and, therefore, sensitively to, the facts" (Cohen 2008a, 256); and (2) "Mine is the a priori thesis that, if facts ground principles, then fact-free principles are at the foundation of the structure of the belief of anyone who is clear about what he believes and why he believes it" (Cohen 2008a, 257). But, Cohen has made no attempt to show that to deny either of the above two mentioned theses is to be involved in a contradiction or to be in conflict with what he 
calls elsewhere "the rule of reason" (Cohen 2000, xxii-xxiv). Moreover, to deny (1) and (2) does not seem to be contradictory. In fact, if my prior argument is sound concerning the claim that all principles are part of an interconnected cluster of propositions (sentences if you will), containing empirical propositions, rules, principles and norms of various sorts, then these alleged ultimate principles are in reality just deeply embedded principles in that practice of interlocked beliefs where no principles are ultimate in Cohen's sense. If this is so, the ground is taken out from under his claim about there being foundational ultimate fact-insensitive principles. It is factually false that 1 and 2 are true. Far from being a priori propositions, 1 and 2 turn out to be non-a priori propositions and false ones at that.

\section{IX}

However, that for the nonce aside, Cohen has given us no grounds for claiming they are substantive a priori principles, in some deep sense independent of our use of language (our use of a particular language, and thus a contingent matter). Nor that it can be a priori true in all possible languages or a priori true independently of any language or indeed be so in any language. Given our use of our language, 'Puppies are young dogs', 'Brothers are male siblings', are a priori. But that requires an empirical fact about English for it to be so. English use could have been otherwise and it is possible, though (to put it mildly) not likely, in the future it might so change. And given (another empirical assumption) that the key terms in those English-language sentences have at least rough synonyms in all other languages - radical translation to the contrary notwithstandingthen these are also language-dependent, but for all that somehow a priori propositions can, in that sense (a particular language-independent sense) be a priori and to the extent that all languages have such synonyms then we can speak of them as linguistic universals, e.g., that 'Puppies are young dogs' will have their equivalents in all languages. But whether or not they do is itself an empirical matter. When push comes to shove we have an empirical and thus contingent matter, namely, whether there are such equivalencies in all languages. Because of this the very idea of fact-insensitive ultimate principles is problematic.

However, Cohen's key sentences (or propositions) appear not to be $a$ priori and he has given us no reason to think they are not dependent on the contingent matter of use. There is no sense of the possibility of a cut away from the empirical. Contingency seems, (pace Cohen) to go all the way down. 
There is another place where Cohen's claim should be questioned. When we come out with moral truisms like 'Promises must be kept' 'Torture must never be practiced', 'Respect for all human beings must be shown' these truisms (true for all of that), carry tacit ceteris paribus qualifiers. For the torture one, remember in the film The Battle of Algiers the ticking bomb scenario where the French officer directing torture was careful to see that no more pain was inflicted than necessary, there being no other means of attaining the necessary information rapidly enough to locate the bomb before it exploded with what would be the consequence of killing many people, some of themchildren-completely innocent. 'Respect for all humans must be shown' seems not subject to an implicit ceteris paribus. But, even that may be questioned. Consider the Hitlers of the world. But what of respect for all human beings with respect-worthy characteristics? Well, perhaps? But even here there perhaps are contingencies (Nielsen 2000).

The prohibition on torture principle was treated by Cohen as a fact-insensitive principle but, if my above remarks are on the mark, unsuccessfully. But 'Respect for all those having respect-worthy characteristics' might be taken as the fact-insensitive backup for respect for persons. There are at least two troubling things here. (1) The term 'respect-worthy' is a thick normative descriptive evaluative term, which has both a descriptive and a normative force, a force which does not unscramble (pace R. M. Hare) into purely factual and purely normative components. But this means that 'Respect for all those having respect-worthy characteristics' is itself fact-sensitive. (But suppose it is taken hypothetically?) (2) It is a factual issue whether all humans in fact have respectworthy characteristics. So it must be shown that respect for all human beings is a factinsensitive principle, though 'Have respect for all those having respect-worthy characteristics' is perhaps itself fact-insensitive. But tautological and thus empty. If not? Then back to 1. My argument is not conclusive here and I am not sure that anything would make it conclusive or even right, but still it needs to be contended with.

Cohen treats matters here hypothetically, namely, 'If human beings have respectworthy characteristics, then they should be treated with respect' and that is the principal type principle that Cohen takes to be fact-insensitive. Moreover, if we withdraw the appeal of requiring respect-worthy qualities and say instead 'All humans in some way should be shown respect', we clearly get something substantive and not merely hypothetical and perhaps a priori and thus empty. But it is implausible to claim that that proposition is a priori. We run up against the problem of the existence of the not inconsiderable number of human monsters who populate or have populated the planet, some notoriously historically relevant on a grand scale on the world stage, many more who are equally vicious but more locally so and again the many who are just privately 
vicious, 'the unsung heroes' contributing to our brutal and savage world. (Remember Michael Haneke's depictions in his film, Ruban Blanc.)

Should we respect Hitler, Stalin, Papa Doc and Baby Doc, Pinochet, Saddam Hussein, Ariel Sharon, George W. Bush, Dick Cheney, or Donald Rumsfeld, all with few, if any, respect-worthy characteristics? (I do not deny that some of these individuals are/were more monstrous than others.) Should they all, just because they are human beings, be respected? Or should we say, even in the face of their monsterhood, that just in being human, they, as everyone else, should be in some way respected? Does in some way' give us some non-Cohenish wiggle room? There will be some people who will say that at least the worst ones, e.g., Hitler, should not be treated with any respect at all. However, in appealing to 'all human beings must in some way be treated with respect' do we have an ultimate fact-insensitive principle? (It is tricky here, for 'in some way' and our use of 'human being' as distinct from 'homo sapiens' raises fact-sensitive issues.)

Probably as a minority, I would say 'Monsters or not, with respect-worthy characteristics or not, these human monsters should in some way be respected.' I am not sure whether that principle is fact-insensitive or not. But 'in some way' counts against it being so. It is surely contestable-what in the old days was mistakenly called 'essentially contestable'-and far from obvious who is right or how we could determine here who, if anyone, is right or even more nearly right. Even though Saddam Hussein was a revolting thug, an evil monster and plainly so, it was wrong-and plainly so-to have taunted him as he was being executed and that even Hitler (our prime paradigm of a really evil man) if he could have been captured should have been given a genuinely, as far as that was possible, fair trial and, with what would doubtless have been the judgment guilty, have either been executed (without taunting) or given life imprisonment without parole at hard but, if possible, socially useful labor or, if found not guilty on grounds of being insane, be put in an insane asylum out of harm's way both to others who he might harm and from harming himself. No suicide option for him.

I can understand the reaction of many French (and not only French) who, seeing the condition of former concentration camp prisoners returning to France, said 'All Germans should be killed'. But plainly, if understandable, it is both irrational and very wrong (Duras 2006, 127-47). But many with the 'kill them all' attitude actually did take a moral point of view. They would say that a captured Hitler without trial should have been treated like a mad dog running loose in the street and just shot without further ado. The relevant point here is that neither my stance nor the opposite stance articulates an $a$ priori truth just clear to the light of reason. Even for, in a Quinean sense, very ultimate principles, there is no such fact-insensitive, fact-independent, a priori or otherwise, ultimate normativity with any substantivity that cannot intelligibly be denied. That is true for mine as well as those of my opponents. What counts as 'being respect-worthy' 
and what it is to treat someone with respect is in part a factual matter. We couldn't even understand that principle without an understanding that is fact-sensitive.

\section{XI}

However, Cohen persists. Perhaps he would think that, even for the old atheist that I am, my beliefs here are religiose? What we need from Cohen are arguments or, as Wittgenstein would say, perspicuous representations. But Cohen believes in essences, believes that both rationality and justice have an essential nature. In all possible worlds the concept of rationality and the concept of justice have necessary and sufficient conditions; the same conditions that obtain for what would be rational and just in all possible worlds. And we must, Cohen has it, investigate these matters a priori; that is, just intuit them. This seems for him a defining feature of what makes an issue philosophical. He even says, at least seemingly messing up his own account, that he does not "think that it prejudices the a priori status of claims about the nature of rationality that we would be inclined to reject a characterization of rationality if it had the consequence that most people were very irrational most of the time" (Cohen 2008a, 257). This seems more in accordance with a Moorean-Ryleian translation into the concrete than with an essentialism. I would reject Cohen's claims here about rationality having an essence.

I believe there is a lot of irrationality going on, much more than most of us expect. Why do both Cohen and I think that a proper conception of rationality could not have it that most people are most of the time irrational? Why could that not be compatible with the concept of rationality? Why do most of us think that way and how would or could we warrant that? Why do we think, even when we also think that there is a lot of irrationality around? Do we empirically determine that most people are not irrational most of the time? If not that way, then how? Is it an a priori matter whether that is so about rationality? I, like many others, think that neither rationality nor justice nor, for that matter, anything social or psychological has an essential nature. There may be natural kinds in chemistry but there are no social or psychological natural kinds. We determine that empirically by examining the uses of the words 'rationality' and 'justice' and their (perhaps only partial) cognates in other languages.

When we do this carefully we understand that we do not and cannot, except arbitrarily stipulatively, determine such matters. Such stipulations are empirical acts, e.g., 'justice' is used this way. There is nothing fact-insensitive here or anywhere along the line, no necessary and sufficient conditions for something being rational or just. Is there any compelling, good reason, warranting us to believe "that anyone who is entirely clear about what her principles are and why she holds them has principles that are independent of her beliefs about facts" (Cohen 2008a, 257)? I don't see that Cohen has established that or even come near to doing so or even made it a plausible assumption. 
Cohen is an essentialist; he aspires to know that there are essences and what essences are and in particular to know what justice is as such, what justice essentially is, what justice in its purity is, what the very nature of justice is, what are the necessary and sufficient conditions of justice, namely, what are the properties that all and only just acts, just principles, just rules, just attributes, just practices, a just ethos and the like have. Its essence is the basic or primary element of justice, that which it could not be lacking without the very idea of justice ceasing to exist, to be conceivable and consistently thinkable. (But, again, that is an empirical matter.) Justice is thought by Cohen to be a natural kind such as water or salt.

Anti-essentialists, by contrast, say that for anything or any activity, or at least for any social or psychological thing, there is no such thing as its intrinsic nature. Rather, all properties are relational. Perhaps that is too strong? But clearly, not all things have essences. Take the number 12. We have not the foggiest idea of what its essence would be. All of the numbers with their infinitely different relations to many other numbers are in internal relations. None of these relations could be different without a number, say 12, being different. How could we ascertain the essence of twelve-hood short of finding some mechanism for generating all the true descriptions of 12 , specifying all its relations to all the other numbers? Vis-à-vis this, Richard Rorty remarks:

Mathematicians can in fact produce such a mechanism by axiomatizing arithmetic, or by reducing numbers to sets and axiomatizing set theory. But if the mathematician then points to his neat little batch of axioms and says, 'Behold the essence of 17!' we feel gypped. There is nothing very seventeenish about those axioms, for they are equally the essence of 1 , or 2 , of 289 , and of $1,678,922$.

...whatever sorts of things may have intrinsic natures, numbers do not-...it simply does not pay to be an essentialist about numbers... it also does not pay to be essentialist about tables, stars, electrons, human beings, academic disciplines, social institutions, or anything else. ...all such objects ...resembl(e) numbers in the following respect: there is nothing to be known about them except an initially large, and forever expandable, web of relations to other objects. Everything that can serve as the term of a relation can be dissolved into another set of relations, and so on for ever. There are, so to speak, relations all the way down, all the way up, and all the way out in every direction...

To say that relations go all the way down is a corollary of psychological nominalism: of the doctrine that there is nothing to be known about anything save what is stated in sentences describing it. For every sentence 
about an object is an explicit description of its relation to one or more other objects (Rorty 1999, 53-54).

However, the essentialist will respond that all properties are not relational. We cannot have relations without things to be related. If there were not, for example, a hard, substantial autonomous table for us to stand in relation to, constituted out of hard, substantial, elementary particles, there would be nothing to get related to and so no relations there. There is, as an untutored common sense insists, "a difference between relations and the things that get related, and philosophy cannot break that distinction down" (Rorty 1999, 55).

The anti-essentialist reply is that "all that we know about this hard, substantial table [about the thing that gets related as opposed to its relations] is that certain sentences are true of it" (Rorty 1999, 55). We know "a given table is rectangular, brown, ugly, made out of a tree, smaller than a house, larger than a mouse, and so on indefinitely" (Rorty 1999, 55). We never get a characterization of its intrinsic nature-something that has necessary and sufficient conditions, a set of properties common to and distinctive of all tables. Moreover, all things are like that: devoid of intrinsic properties.

An essentialist will at that point go anti-linguistic and refuse to admit that language provides our only cognitive access to objects, claiming that we "must have some prelinguistic knowledge of objects"-some knowledge by acquaintance (Rorty 1999, 56). An empiricist trying to be an essentialist might try to demonstrate his knowledge by acquaintance by banging his hand on the table or telling us to do the same and just feel or look, thereby freeing ourselves of any verbal characterization of what we feel or see, thereby revealing our "knowledge of the table's intrinsic causal powers, its sheer brute thereness" (Rorty 1999, 56). But we will never get a sheer thereness or thisness that yields any understanding. This shows, Rorty claims, something that an empiricist trying to be an essentialist claims, but it will not put us just brutely in touch with reality: the distinctive things that we in everyday life are aware of. The anti-essentialist, who at this point will be accused by not a few (unfairly I think) of being an unwitting linguistic idealist, will not acknowledge, and cannot make sense of, an allegedly purely ostensive identification or knowing, a brute knowledge by acquaintance. Remember Wittgenstein's reminder that any ostensive definition can be variously interpreted in every case. By itself it is just taken by empiricist as an inarticulate brute thisness or thereness (whatever these are).

However, we do not "get on more intimate terms with the table, closer to its intrinsic nature, by hitting than by looking at it or talking about it" (Rorty 1999, 56). Such banging, touching, or looking and similarly allegedly purely ostensive matters do not succeed in taking one out of language into fact, into some direct non-linguistic awareness of how things really are. Rorty goes on to say: 
Unfazed... the antiessentialist reiterates that if you want to know what the table really, intrinsically, is, the best answer you are going to get is 'that of which the following statements are true: it is brown, ugly, painful to banging heads, capable of being stumbled over, made of atoms, and so on and on.' The painfulness, the solidity, and the causal powers of the table are on all fours with its brownness and its ugliness. Just as you do not get on more intimate terms with the number 17 by discovering its square root, you do not get on more intimate terms with the table, closer to its intrinsic nature, by hitting it than by looking at it or talking about it. All that hitting it, or decomposing it into atoms, does is to enable you to relate it to a few more things....

The... anti-essentialist denies that there is a way to pick out an object from the rest of the universe except as the object of which a certain set of sentences are true. With Wittgenstein, he says that ostention only works against the backdrop of a linguistic practice, and that the self-identity of the thing picked out is itself description-relative. Anti-essentialists think that the distinction between things related and relations is just an alternative way of making the distinction between what we are talking about and what we say about it. The latter distinction is, as Whitehead said, just a hypostatization of the relation between linguistic subject and linguistic predicate.

Only when linked up with some other parts of speech does a noun have a use, and only as the term of a relation is an object an object of knowledge. There is no knowledge of the subject without knowledge of what sentences referring to it are true, just as there is no knowledge of a number without knowledge of its relations to other numbers (Rorty 1999, 56-57).

Still, Cohen digs in his heels. He remarks in his chapter on constructivism (Chapter 7):

I agree with the Socratic-Platonic view that led Socrates to reject illustrations of, for example, just behavior as providing a proper answer to the question "What is Justice?": no list of examples reveals what it is about the examples that makes each an example of justice. Until we unearth the fact-free principle that governs our fact-loaded particular judgments about justice, we don't know why we think what we think just is just. And we have to retreat to (what we consider to be) justice in its purity to figure out how to institute as much justice as possible inside the cave. 
The "lovers of sights and sounds" in Book V of Plato's Republic think it suffices for saying what justice is to say what counts as just within the world of sights and sounds. They scarcely recognize the question What is justice, as such? In a world where the facts are $F$, they believe that $P$ constitutes justice, and they do not abstract even so far as to see that they believe, independently of the facts, principles of the form if $F$ then $P$. Plato thinks, and I agree, that you need to have a view of what justice itself is to recognize that justice dictates $P$ when $F$ is true. That is how justice transcends the facts of the world (Cohen 2008a, 291).

I am not a Platonist, an essentialist, an empiricist trying also-as Rorty describes above - to be an essentialist, nor am I a linguistic idealist. To use Plato's metaphor, we can only say what justice is, know what justice is or indeed any other moral or normative notion is, from within the world of sights and sounds. To know what justice is or any such notion we have to (pace Plato and Cohen) translate into the concrete after the fashion of Moore, Wittgenstein and Ryle of Cambridge and Oxford tradition of philosophy of the mid-twentieth century. Without essences we live comfortably in the world of sights and sounds. We need not and perhaps cannot know, what justice is in itself but we know that to cheat someone is to be unjust to him and to give someone the correct change when he buys something from us is to treat someone justly. To be fair is to be just gives us nothing substantive anymore than to say a brother is a male sibling. Translations into the concrete are more reliable in ascertaining justice than philosophical generalizations of what the essential (intrinsic) nature of so called 'pure justice' is. Any philosophical generalization is plainly false which gave us to understand that there was nothing unjust in such things as having a swimming pool that takes up your neighbor's only source of drinking water, or a situation where twenty thousand children a day unnecessarily die of malnutrition or of easily curable diseases while the rich nations of the North, partly responsible for that situation, do nothing or next to nothing about it when they easily could with no great sacrifice eradicate it or at least extensively diminish it. No talk about the essence of justice is going to gainsay that or help us get clearer about that. This is not just a matter of ascertaining pace Cohen when justice can be implemented, though surely it is also that, but the surest way of determining what justice is. This should be a lesson-to go philosophical-derived from G. E. Moore's "A Defense of Common Sense" or C. S. Peirce's defense of critical commonsensism.

Joshua Cohen argues against G. A. Cohen (J. Cohen 2001). In this dispute, G. A. Cohen agrees with Joshua Cohen that the facts determine what questions of justice will arise from a practical point of view (Cohen 2008a, 267). But then G. A. Cohen rebuts: 
Now it is indeed true that to decide what to do we need say nothing definite, and, in fact, nothing at all, about that [i.e., about what justice, as such, is]. But suppose that, like me, you think that political philosophy is a branch of philosophy, whose output is consequential for practice, but not limited in significance to its consequences for practice. Then you may, as I would, protest that the question for political philosophy is not what we should do but what we should think, even when what we should think makes no practical difference. Given the claim that the world forces no choice between the difference principle and the principle of not having too much inequality, a certain decision about fundamental principle has no practical significance. But fundamental principles retain practical significance even here, because it is by appeal to them, together with the facts, that the maximinizing policy is justified (Cohen 2008a, 263).

But in the last sentences of the above quotation, G. A. Cohen is unsaying what he said in the first three sentences and seems to be embracing the pragmatist principle that what makes no difference in practice is no difference and this seems at least to nicely fit with Joshua Cohen's claims. If this makes philosophy futile, then so be it. Cohen needs to show that the practice of philosophy, at least as he does it, has an output which is consequential for practice.

\section{XII}

One can reasonably be socialist (as Cohen was and remained) ${ }^{1}$ and have a coherent moral and political orientation, without being philosophically conservative as Cohen also came to be, in an essentialist tradition going back to Plato that does not set well with a Marxist orientation. There is no conceptual link between one's politics and one's philosophy, common belief to the contrary notwithstanding. If so, what is the relevance of what I have said here for readers of Socialist Studies?

\footnotetext{
${ }^{1}$ It was said by some at the conference from which most of the papers in this volume are drawn that Cohen abandoned his Marxism and socialism. Both are absurdly false. He, ever since his graduate school days, had abandoned fundamentalist Marxism. But 'fundamentalist Marxism' is not pleonastic and 'analytic Marxism' is not an oxymoron. Cohen was and remained an analytical Marxist and socialist until the end of his life. Another absurd falsehood floated around the conference was that Cohen was a 'closet libertarian'. Nothing could be further from the truth. Liberty for him was, of course, a value but not the primary value overriding all other values. Cohen, like his friend, Isaiah Berlin, was a pluralist about fundamental values. Here see Cohen 1996, 7-25; 2000, xvii-xxviii; 2001, 11-18; and 2009.
} 
Cohen, with his articulation, defense and subsequent modifications (but not abandonment) of historical materialism, has made a crucial contribution to Marxist (or what would be better called scientific socialist) theory and consequentially to scientific socialist practice. Cohen has given us an account of a form of epochal social change that is directional in history without construing history has having a telos, something mysteriously, and probably incoherently, having an end, an aim, a purpose without a purposer or purposers. In the face of Berlin, Popper and a host of lesser lights, Cohen gave us a socialism that had a causal, though still functional, scientific empirically grounded account of epochal social change, something of crucial significance for socialism in theory and practice-an account of historical change both scientific and directional without being metaphysical and obscurantist.

Cohen subsequently became increasingly interested in moral philosophy, in conflict with Marxist amoralism; the claim that thinking about morality or constructing moral theories was thoroughly negatively ideological. I think that the Marxist amoralists were right in claiming that what we socialists need is not the articulation of moral views or a development of moral theory but instead an attention to class interests and particularly to working class interests. We should, Marxist amoralists maintain, eschew appeals to morality, moral philosophy or trying to ascertain and then take a moral point of view (Cohen 1981; Wood 1972, 1984, 1985; Nielsen 1987, 1989, 1991, 1998).

Cohen's long awaited big book on moral philosophy, Rescuing Justice and Equality (2008), intends to help us, among other things, in the project of developing a genuinely scientific socialism that is not a Marxist amoralism but that articulates a moral theory. However, even if his meta-ethical account is on the mark, if my argument is right, it is irrelevant to socialism, neither supporting it nor in any way undermining it. Our central concerns as socialists are to understand the world, to change the world and to understand how to change it for the better. But in so acting and thinking we need not and should not bother to understand, Cohen's meta-ethical questions, his claimed moral foundations or any such foundations. We need not have a theory of a better world or a philosophical analysis of 'better'.

In a 1996 interview, Cohen said that he had come to think that continued consideration of historical materialism was not terribly important as distinct from his belief that "normative questions are desperately important" (Cohen 1996, 11). I too think there are normative questions, some of which are desperately important. But not all of them. Is one wine better than another? Is heterosexual marriage better than gay marriage? These are plainly normative questions, but not desperately important. They are not like whether undocumented immigrants should be deported, which is desperately important to answer. Moreover, whether we could have too much equality or too much liberty can entangle the minds of some philosophers, but should be put on the back burner when we are struggling to change our world from the dreadful one we live in now 
(2011). What is crucial is to determine what must be done to have a decent world and what we have to know and do to get it or even approximate it. Particularly looked at globally, we start in determining and doing this at a very low level. The metaphors for our world as a pigsty and a global insane asylum, depending on whether we are thinking of global poverty or global warming, are very appropriate.

Given the structure of class interests in the world, we realistically can have little decency, as far as public affairs go, for the foreseeable future. Is this, try as we will, something that is empirically impossible? Here, morally speaking as far as much philosophy is concerned, issues turn around historical meta-ethical issues such as ones concerning whether ultimate moral principles are fact-insensitive or not or the normative ethical theory problem of whether we should seek a principle of equality that is more egalitarian than the difference principle. However, if we are serious about the struggle for a better world, we have more crucial concerns for example, how to eliminate or, lessen the deep and deepening inequalities both between societies and within them and the poverty that goes with this. Global warming is another instance. How do we effectively struggle against a social order which irrationally does precious little when, vis-à-vis the human livability of our climate, time is running out (Harvey 2011, 1-2)? This is where the action should be. Normative issues like these are desperately important-not the meta-ethical ones Cohen discusses in Rescuing Justice and Equality or the abstract normative ethical ones that Cohen also discusses as when he sets his view of equality against Rawls's or against libertarian claims concerning the priority liberty.

This is not to deny what is abundantly evident: Cohen's brilliance, acuteness and intense intellectual integrity. But as a socialist, an activist seeking to help us along in changing the world for the better and as a public intellectual his later writing takes us on the wrong track, contrasting markedly, and, for human and socialist practicability, for the worse, with his masterful work on historical materialism. We do not need to get clear about distinctively philosophical issues to be clear about, to come to grips with and confront the issues that both progressive theoreticians and activists (sometimes one and the same) confront. Instead, we should "focus on describing and analyzing social, economic and/or political injustice, and practices of struggle, transformation and liberation", to quote from the website of Socialist Studies.

Am I being too parti-pris? I both hope and think not. But I would not be the first or last to be self-deceived. ${ }^{1}$ Self-deceived or not, what is most fundamentally at issue between Cohen and myself is what we socialist public intellectuals should be doing. In

\footnotetext{
${ }^{1}$ When I first met Jerry Cohen, at a conference at the University of Texas at Austin, we soon realized that we were birds of a feather. We talked late into the night. At the end of it, Jerry said to me, "Kai, you are too parti-pris but then you're a convert." I realized that, unlike him, I did not have the good fortune (bad fortune?) to be a red diaper baby. I hope I am not parti-pris, but I recognize that it is hard not to be over something one cares about deeply.
} 
my Wittgensteinian therapeutic philosophical manner, I say that we should, if we can, bid goodbye to philosophy, at least as conceived and practiced by most philosophers, excluding many rigorously analytical ones (Nielsen 1989). ${ }^{1}$ We need not go philosophist before we can understand and help change the world into a better world or recognize that a better world is possible. That requires no philosophical expertise or insight. Rather, philosophy usually gets in the way.

But the most important thing is that both Cohen and me, and many more, would be on the same side of the barricades, all welcoming a successful socialist revolution that was actually taking place. We are, unfortunately, a long way from that now. But the struggle goes on and in this struggle I think we should say farewell to philosophy. We should remember, as Marx and Engels said in The German Ideology, that philosophy is to science as onanism is to coitus. We want a firm scientific basis for our socialism. But arm waving at that as many intellectuals and officials in the Soviet Union did and as Althusser and his followers did will not give us that. We want, and should struggle to achieve, something genuinely scientific to be rooted in socialist practice.

\section{References}

Barry, Brian (2005): Why Social Justice Matters. London, UK: Polity Press.

Cohen, G. A. (1981): “Freedom, Justice and Capitalism.” New Left Review 126, 3-16.

(1996): "Self-Ownership, History and Socialism: An Interview with G. A. Cohen." Imprints 1, no. 1, 7-25.

(2000): “'Reflections on Analytical Marxism." In G. A. Cohen, Karl Marx's Theory of History: A Defense, Expanded Edition. Princeton, NJ: Princeton University Press, xvii-xxviii.

(2001): “A Brief Look at Socialism: An Interview with G. A. Cohen.” Pensées 2, $11-18$.

\footnotetext{
${ }^{1}$ I call myself a maverick analytical Marxist because I reject methodological individualism and am instead a modest holist, though not a Hegelian dialectical one. I am an anti-essentialist, anti-foundationalist and a historicist contextualist perspectivist. These things set me apart from standard analytical Marxists such as Cohen, but like them I remain committed to analytical methods. I explicate and defend this in my On Emancipatory Social Science (forthcoming).
} 
(2008a): Rescuing Justice and Equality. Cambridge, MA: Harvard University Press.

(2008b): "Rescuing Justice from Constructivism and Equality from the Basic Structure Restriction.” Unpublished manuscript, 1-21.

(2009): Why Not Socialism? Princeton, NJ: Princeton University Press.

Cohen, Joshua (2001): “Taking People as They Are." Philosophy and Public Affairs 30, 363-86.

Daniels, Norman (1996): Justice and Justification: Reflective Equilibrium in Theory and Practice. Cambridge, UK: Cambridge University Press.

Duras, Marguerite (2006): War Time Stories.

Harvey, Fiona (2011): “World Climate Now 'On the Brink'” The Guardian Weekly, 1-2.

Malcolm, Norman (1963): Knowledge and Certainty. Englewood Cliffs, NJ: PrenticeHall.

Moore, G. E. (1950): Philosophical Papers. London, UK: Unwin Brothers.

(1953): Some Main Problems of Philosophy. London, UK: George Allen \& Unwin.

Nielsen, Kai (1971): “On the Choice Between Reform and Revolution.” Inquiry 14, no. 1, 271-95.

(1984): Equality and Liberty: A Defense of Radical Egalitarianism. Totowa, NJ: Rowman and Littlefield.

(1985): “On Finding One’s Feet in Philosophy: From Wittgenstein to Marx." Metaphilosophy 16, no. 1, 1-11.

(1987): “Coming to Grips with Marxist Anti-Moralism." Philosophical Forum 18 , no. $1,1-22$.

(1989): Marxism and the Moral Point of View. Boulder, CO: Westview Press. 
(1991a): God and the Grounding of Morality. Ottawa, ON: University of Ottawa Press.

(1991b): “Does a Marxian Critical Theory of Society need a Moral Theory?" Radical Philosophy 59, 21-26.

(1994): "Philosophy within the Limits of Wide Reflective Equilibrium Alone." Iyyun 43, 3-41.

(1998): "Justice and Modes of Production: Allen Wood's 'The Marxian Critique of Justice'." In Joram Heber and Mark Halfon, eds., Norms and Values: Essays on the Works of Virginia Held. Lanham, MD: Rowman and Littlefield, 267-81.

(2000): “There is No Dilemma of Dirty Hands." In Paul Rynard and David Shugarman, eds., Cruelty and Deception. Peterborough, ON: Broadview Press, 139-56.

(2008): “On There Being Wide Reflective Equilibria: Why it is Important to Put it in the Plural." Windsor Yearbook of Access to Justice Vol. 26, Issue 2, 219-52.

Nowell-Smith, P. H. (1954): Ethics. London, UK: Penguin Books.

Putnam, Hilary (2002): The Collapse of the Fact/Value Dichotomy. Cambridge, MA: Harvard University Press.

Rawls, John (1999a): A Theory of Justice. Revised edition. Cambridge, MA: Belknap Press of Harvard University Press.

(1999b): Collected Papers. Edited by Samuel Freeman. Cambridge, MA: Harvard University Press.

Ripstein, Arthur (2010): “Critical Notice of G. A. Cohen's Rescuing Justice and Equality." Canadian Journal of Philosophy Vol. 40, no. 4, 669-99.

Rorty, Richard (1999): Philosophy and Social Hope. London, UK: Penguin Books.

Rorty, Richard and Pascal Engel (2007): What's the Use of Truth? New York, NY: Columbia University Press. 
Ryle, Gilbert (1972): Collected Papers, Volume II. London, UK: Hutchinson, 319-25.

Waismann, Friedrich (1968): How I See Philosophy. New York, NY: St. Martin’s Press, 138.

Wood, Allen (1972): “The Marxian Critique of Justice." Philosophy and Public Affairs 1, 224-82.

(1982): Karl Marx. London, UK: Routledge and Kegan Paul.

(1985): “Marx’s Immoralism." In Bernard Chavance, ed., Marx in Perspective. Paris, FR: Editions de l'Ecole des Haute Etudes en Sciences Sociales, 681-98.

(1993): “Marx against Morality.” In Peter Singer, ed., A Companion to Ethics. Oxford, UK: Wiley-Blackwell, 511-24. 